\title{
ENCONTROS E TENSÕES RELIGIOSAS EM FINADOS
}

\author{
Andreia Vicente da Silva ${ }^{1}$
}

\begin{abstract}
Nós [os frequentadores do cemitério] temos dúvidas. Não sabemos muito bem o que fazer. Não sei o que vai acontecer depois que eu morrer. Aí eu penso: quem é que ta certo? Se eu for pela cabeça deste aqui [e aponta para o folheto] e o certo for aquele lá? [e olha pra Igreja Católica]. Então eu tava aqui lendo [o folheto] e me perguntando: o que eu devo fazer? [...] agora, eu acho uma falta de respeito deles virem aqui hoje. Sabe, nós estamos aqui porque temos muita saudade. Eu sei que lá não tem mais nada. Que meu pai, [sic] que tudo já se foi. Só que o túmulo é um símbolo e venho porque tenho saudade. Agora, ainda tenho que encontrar mais essa. (Érica $\left.{ }^{2}, 02 / 11 / 2008\right)$.
\end{abstract}

No dia dois de novembro celebra-se o Dia dos Mortos. Como é de conhecimento público, no Brasil esta é uma data específica para se lembrar e homenagear aqueles que já faleceram. É um feriado católico que persiste em nosso calendário laico e que movimenta todos os anos milhares de cemitérios brasileiros.

Em Praia de Mauá que é o quinto distrito da cidade de Magé no estado do Rio de Janeiro não é diferente. No distrito, as homenagens aos mortos são realizadas no único cemitério público que fica ao lado da Igreja de Nossa Senhora da Guia construída em 1597 pelos primeiros portugueses que chegaram na região ${ }^{3}$. Atualmente a igreja é tombada pelo Instituto do Patrimônio histórico e Artístico Nacional (IPHAN). Chamo o conjunto arquitetônico composto pela Igreja, pelo cemitério e pela capela Santo Antônio de "Complexo da Guia" - já que o compreendo interligado por sentidos religiosos construídos em processo histórico interdependente.

Minha intenção neste ensaio fotográfico é apresentar algumas dinâmicas dos encontros religiosos observados no cemitério público de Praia de Mauá em trabalho de campo realizado entre os anos de 2008 e 2009. Todavia, o Dia dos mortos é tratado por mim neste ensaio não somente como um dia específico e sim como um "processo" mais alongado no tempo. Afinal, como pretendo demonstrar, a preparação do cemitério e das homenagens se iniciam dias antes do feriado. Nas semanas anteriores ao feriado, o fluxo de pessoas aumenta de maneira intrigante. Os funcionários da prefeitura e os enlutados

\footnotetext{
${ }^{1}$ Universidade Estadual do Oeste do Paraná, Brasil.

${ }^{2} \mathrm{O}$ nome da interlocutora é fictício.

${ }^{3}$ O cemitério de Praia de Mauá surgiu como extensão da igreja ainda no período colonial. Como já foi demonstrado por diversos autores (Reis, 1991; Rodrigues, 2005), durante o período colonial, igreja e cemitério eram uma só construção. A partir dos movimentos higienistas e da separação entre estado e igreja, com o advento da república, os cemitérios foram sendo separados das igrejas e passaram a ser administrador pelo estado. Para uma melhor compreensão de como esse processo ocorreu em Praia de Mauá, remeto o leitor a leitura da minha tese de doutorado (Vicente da Silva, 2011).
} 
realizam diversas atividades que ajudam a criar a atmosfera simbólica propícia para as homenagens do dia de Finados.

Antes de iniciar a narrativa específica de preparação do cemitério e dos (des) encontros religiosos que neste processo ocorrem, é necessário chamar atenção para algumas dinâmicas espaciais específicas. Embora o cemitério como instituição pública e, portanto, laica, esteja aberto para todos, existe um domínio simbólico ritual e territorial em seu interior que é católico. E, mesmo que a predominância do catolicismo seja abrangente em todo Complexo da Guia, observa-se a presença de outros atores na parte externa - em frente a capela Santo Antônio e na rua. Lá, fora da necrópole, os vendedores ambulantes se posicionam e oferecem artigos utilizados por aqueles que desejam homenagear os mortos. A presença evangélica também fica evidente no portão e fora do cemitério visando confrontar os ritos católicos que ali ocorrem.

Nas semanas que antecedem o Dia dos mortos, uma movimentação incomum de pessoas já pode ser observada no campo-santo de Praia de Mauá. Os funcionários da equipe de conservação e limpeza da prefeitura (garis e zeladores) são deslocados para trabalhar no cemitério. Eles capinam, pintam, limpam e lavam os corredores, as paredes, os túmulos, o cruzeiro. O objetivo do mutirão é deixar tudo limpo e asseado para Finados. É de conhecimento público que, no dia dos mortos, muitas pessoas vão ao cemitério. Percebe-se uma valorização, por parte do poder público, dos momentos rituais católicos, tanto pelo fato do mesmo ser considerado feriado quanto pelo fato da prefeitura determinar o cuidado especial com o espaço do carneiro nesse dia.

Ao mesmo tempo em que os zeladores trabalham, o coveiro, recebe muitas visitas de parentes preocupados com o estado de conservação dos túmulos de seus mortos. De acordo com o coveiro' a maior parte dos habitantes que vão a necrópole pedir um zelo específico com as sepulturas são os católicos. Eles pedem que tudo seja arrumado para o dia especial. A aparência dos túmulos deve estar perfeita e deve espelhar uma grande preocupação e cuidado. Tudo deve estar pronto para a visita do feriado. Tanto isso é verdade que muitos parentes vão ao cemitério na véspera do dia especial para limpar pessoalmente as sepulturas de seus mortos. Eles levam baldes, vassouras, produtos de limpeza e fazem uma faxina preparando as sepulturas e os jazigos para as homenagens. 
No dia dois de novembro bem cedinho, ainda antes de amanhecer o dia, já se pode ver vendedores de flores e velas posicionando-se em frente a Capela Santo Antônio. Outros ambulantes vendem sucos e refrigerantes. Uma grande cadeia de produtos e serviços se forma em torno do cemitério visando o cuidado dos mortos e dos vivos. Todos trabalham para que o ritual dos mortos se realize.

O primeiro rito oficial católico no dia de finados em Praia de Mauá é a missa em homenagem aos mortos. Esta celebração inicia-se fora da área do atual cemitério, dentro da Igreja de Nossa Senhora da Guia que fica localizada ao seu lado. Logo após o fim da missa, uma procissão desce o morro da Igreja em direção ao cemitério. A procissão é conduzida por um auxiliar do padre que carrega uma grande cruz. As mulheres que compõem um grupo conhecido como Legião de Maria e o padre são seguidos pela multidão. Todos entram no cemitério e se posicionam rezando e cantando em frente ao Cruzeiro que fica localizado na parte central. Nesse cruzeiro são acesas velas que devem iluminar o caminho dos mortos. As músicas cantadas e as rezas que são feitas têm como eixo principal o tema da petição em favor dos que se foram. Ao ouvirem as súplicas muitas pessoas param e se juntam em oração a esses fiéis. Os enlutados emocionados choram e se abraçam. Numa etapa posterior da ritualização católica, o padre dá a benção dos túmulos que é acompanhada por fiéis e também por pessoas que não pertencem à comunidade católica.

Apesar da descristianização do espaço do cemitério ter acontecido oficialmente no Brasil, a vivência e a observação cotidiana comprovam que o culto dos mortos ainda é predominantemente católico na necrópole pública de Praia de Mauá. A posição do cemitério ao lado da Igreja que é herança do período de colonização católica reforça essa ênfase que é indiscutível já que o padre e seus auxiliares descem da igreja e seguem em direção ao cruzeiro do cemitério para finalizar o rito aos mortos. Há uma continuidade ritual entre igreja e cemitério que evidencia essa predominância.

As participantes da Legião de Maria, responsáveis pelos cantos rituais no cruzeiro explicam que vão ao cemitério para rezar o terço e interceder a Deus pelas almas que precisam de oração. A forma como essas mulheres rezam e cantam pedindo pelos mortos é reveladora da predominância católica sobre o espaço do cemitério. Ao realizarem seus rituais elas invocam pedindo por todos os mortos. Seus pedidos são feitos genericamente, embora tenham em suas mãos um cesto cheio de nomes de mortos que foram depositados ainda na igreja pelos fiéis católicos. O próprio padre, quando 
chega ao cemitério e dá a benção dos túmulos e a palavra final em frente ao cruzeiro, não cita nomes. É uma etapa dirigida a todos os mortos que estão ali sepultados. Qualquer pessoa presente pode participar do ritual e ao mesmo tempo pedir por seu morto particular. Essas rezas e cantos feitos genericamente reforçam ainda mais a abrangência dos rituais do catolicismo na composição das relações entre vivos e mortos.

A continuidade da predominância católica no cemitério no dia dos mortos só é contestada pela presença evangélica. De maneira surpreendente, em finados, os evangélicos também vão ao cemitério, mas não para homenagear os mortos. A ida dos evangélicos a necrópole tem um objetivo diferente. Afinal, a maior parte deles não tem o hábito de cuidar das sepulturas dos seus mortos. Eles evitam essas manifestações como demonstração de desapego ao corpo do morto e como expressão de uma incomunicabilidade com o defunto. Na verdade, os evangélicos vão ao cemitério para praticar proselitismo, comportamento reconhecido historicamente como associado ao protestantismo. Eles distribuem folhetos perto do portão de entrada ou diante da capela funerária. Eles dão os folhetos aos passantes e citam a frase: "Jesus te ama".

A atitude dos evangélicos é intrigante. Embora estejam distribuindo as mensagens bíblicas e pretendam combater os rituais que estão sendo realizados, eles permanecem a maior parte do tempo calados. Esse comportamento contido pode ser lido de várias maneiras. Demonstra, por um lado, que mesmo não concordando com o costume ritual ali realizado eles respeitam àqueles que estão participando de um momento tão cerimonioso e, por outro, mostra que eles entendem - mesmo em combate - os sentidos que dominam aquele espaço.

Entendi, depois de muitas conversas e observações, que os evangélicos vão ao cemitério no dia dos mortos porque acreditam que exista um engano na conduta dos parentes dos mortos. $\mathrm{O}$ ato de cuidar dos túmulos dos mortos e de visitar o cemitério no dia de finados é explicado por meus informantes distribuidores de folhetos como uma forma de supervalorizar a materialidade do corpo e a comunicação com os mortos. Discordando desse hábito, eles desejam oferecer àqueles que estão ali outra opção e por isso praticam o proselitismo.

Os evangélicos explicam que é impossível que os vivos possam ajudar a salvar os mortos do inferno justamente porque a salvação ou a condenação é determinada em vida através do ato individual de aceitação da palavra de Deus. Eles não acreditam na existência do purgatório. Ao mesmo tempo, no que diz respeito ao corpo do morto, os 
evangélicos explicam que "o corpo vira pó e a terra retorna" e que "[esse] corpo não é nada, o importante é a alma". A partir desta crença, eles se colocam diante do cemitério para oferecerem-se como outra opção de salvação da alma dos vivos. Ao entregar os folhetos com - por exemplo - a mensagem "a morte não é o fim" eles explicitam a necessária aceitação do evangelho em vida, o que seria capaz de levar a alma ao céu.

A presença dos evangélicos distribuindo folhetos no cemitério causa enorme constrangimento. Ao chegarem a necrópole, muitos enlutados são abordados por eles. Diversas vezes, aqueles que passam não aceitam os folhetos por se sentirem desrespeitados num momento tão especial. Os católicos se dizem invadidos. Muitos aceitam os folhetos por educação e logo em seguida os jogam no chão. Eles balançam a cabeça desaprovando a rotina evangélica. Depois de ouvirem a frase "Jesus te ama", muitos respondem "com certeza", num tom ríspido de desaprovação. Tanto o cumprimento, quanto a resposta, evidenciam a "contraposição" discursiva contida entre católicos e evangélicos. Por outro lado, há alguma curiosidade sobre o que está escrito nos folhetos distribuídos ou a respeito do que significa a presença dos evangélicos ali. Algumas vezes vi pessoas paradas ou sentadas nos bancos e nas calçadas ao lado da capela, lendo os folhetos ou conversando com aqueles que evangelizavam.

De fato, o Dia dos Mortos é uma ocasião especial para perceber o compartilhamento do espaço público laico por diferentes atores religiosos. Os frequentadores e frequentadoras do cemitério estão entre as alternativas religiosas que se oferecem neste espaço. A ocupação do cemitério por católicos e evangélicos expressa os sentidos que constroem aquele território e quais os limites e tensões existentes nos (des) encontros no espaço público compartilhado. 


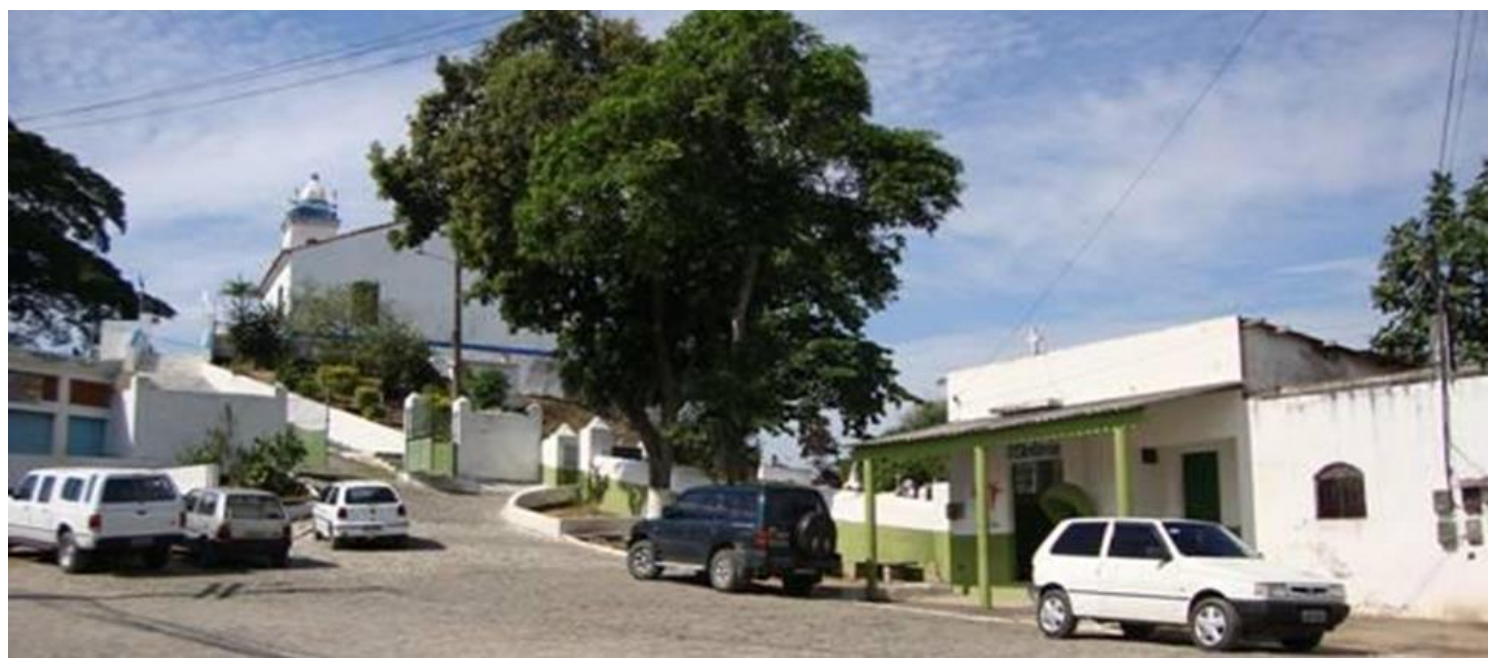

Foto 1 - Diante do complexo da Guia, da direita para a esquerda: Capela Santo Antônio, portão do Cemitério, Igreja de Nossa Senhora da Guia. Foto: Andreia Vicente.

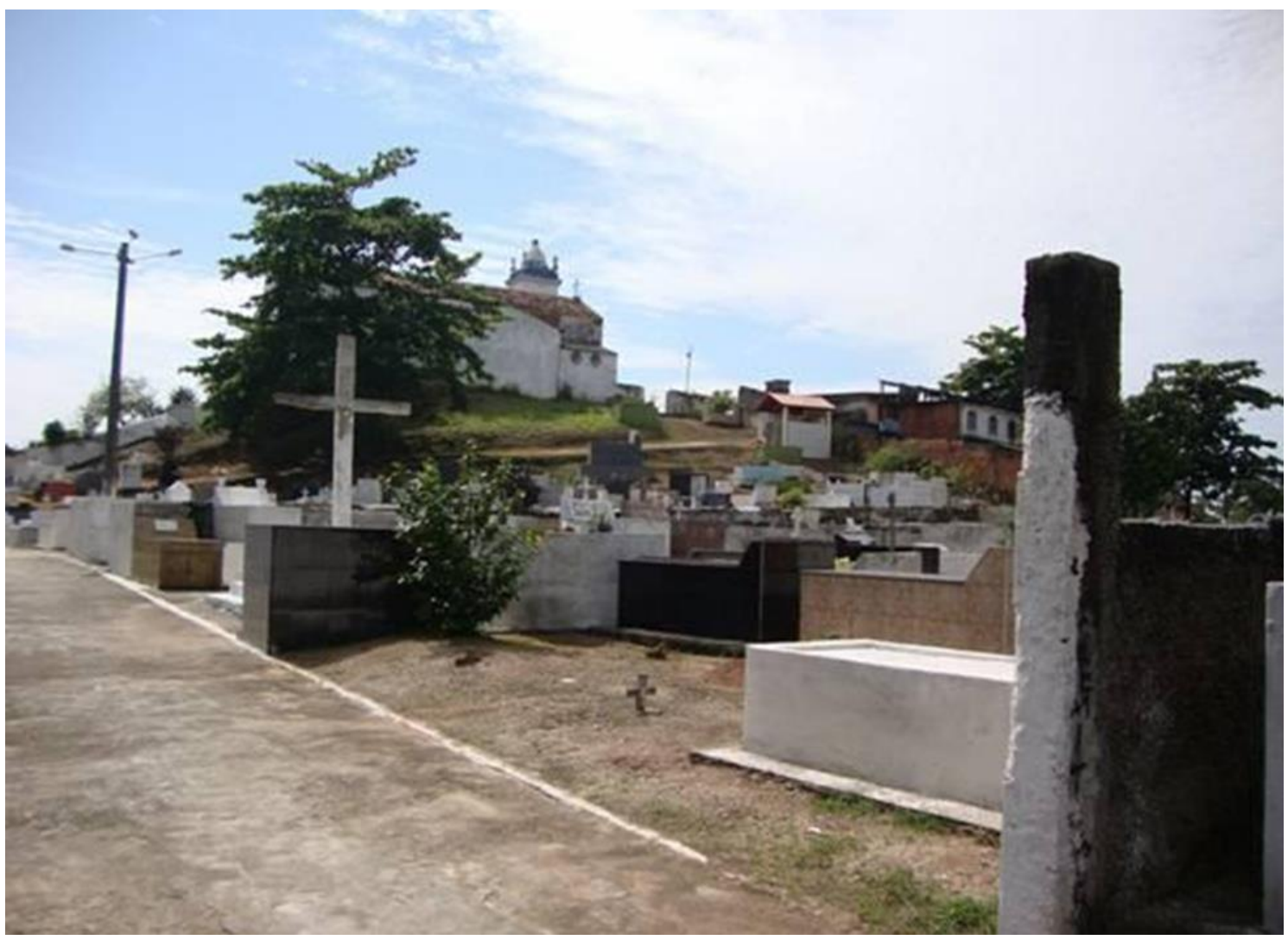

Foto 2 - Vista de dentro do cemitério: em frente está o cruzeiro e ao fundo a Igreja de Nossa Senhora da Guia. A proximidade entre a Igreja e o cemitério e a presença do cruzeiro comprovam a predominância do catolicismo na necrópole. Foto: Andreia Vicente. 


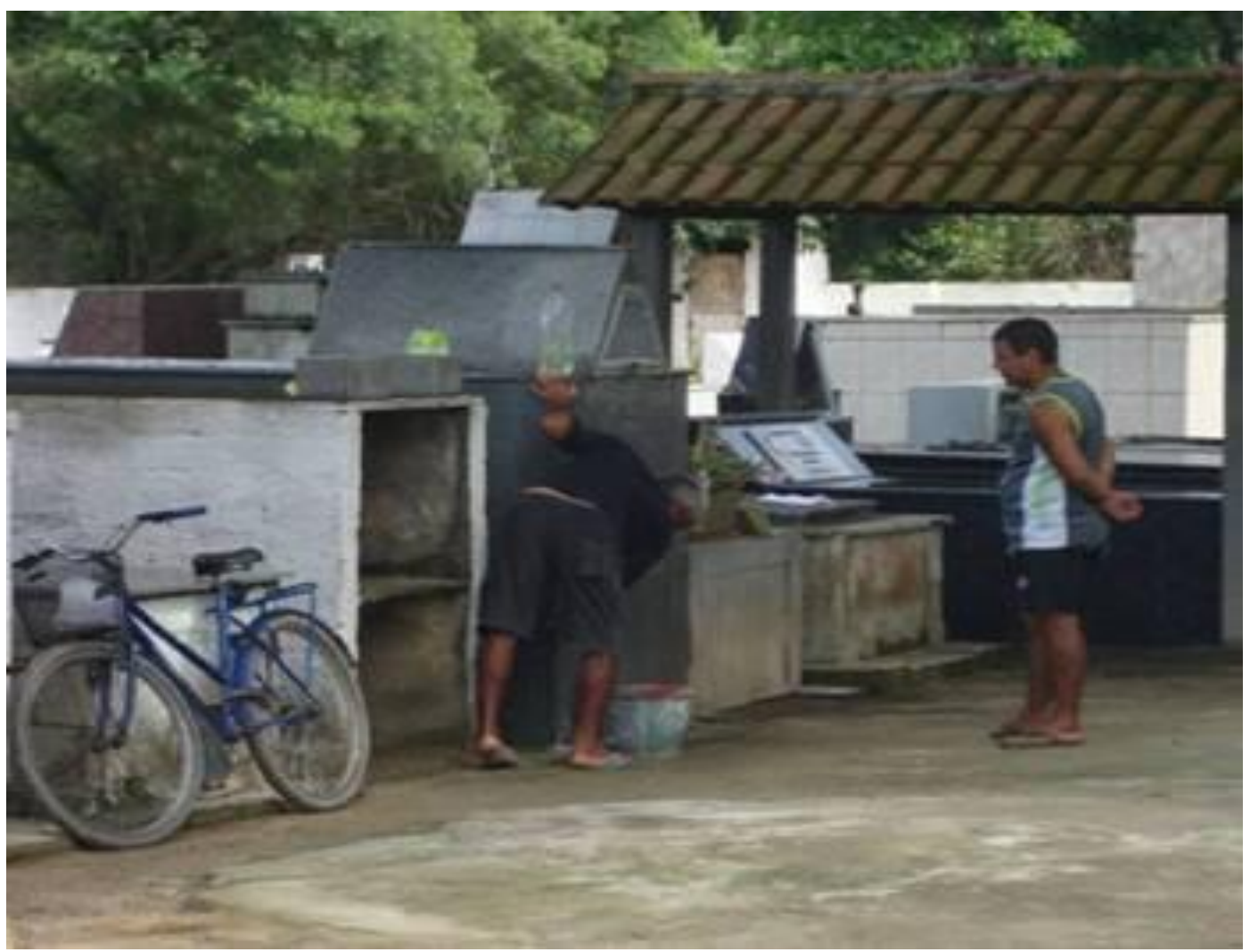

Foto 3 - O coveiro agachado limpava um túmulo. Nota-se a presença de utensílios: balde e garrafa pet com produtos de limpeza. Foto: Andreia Vicente.

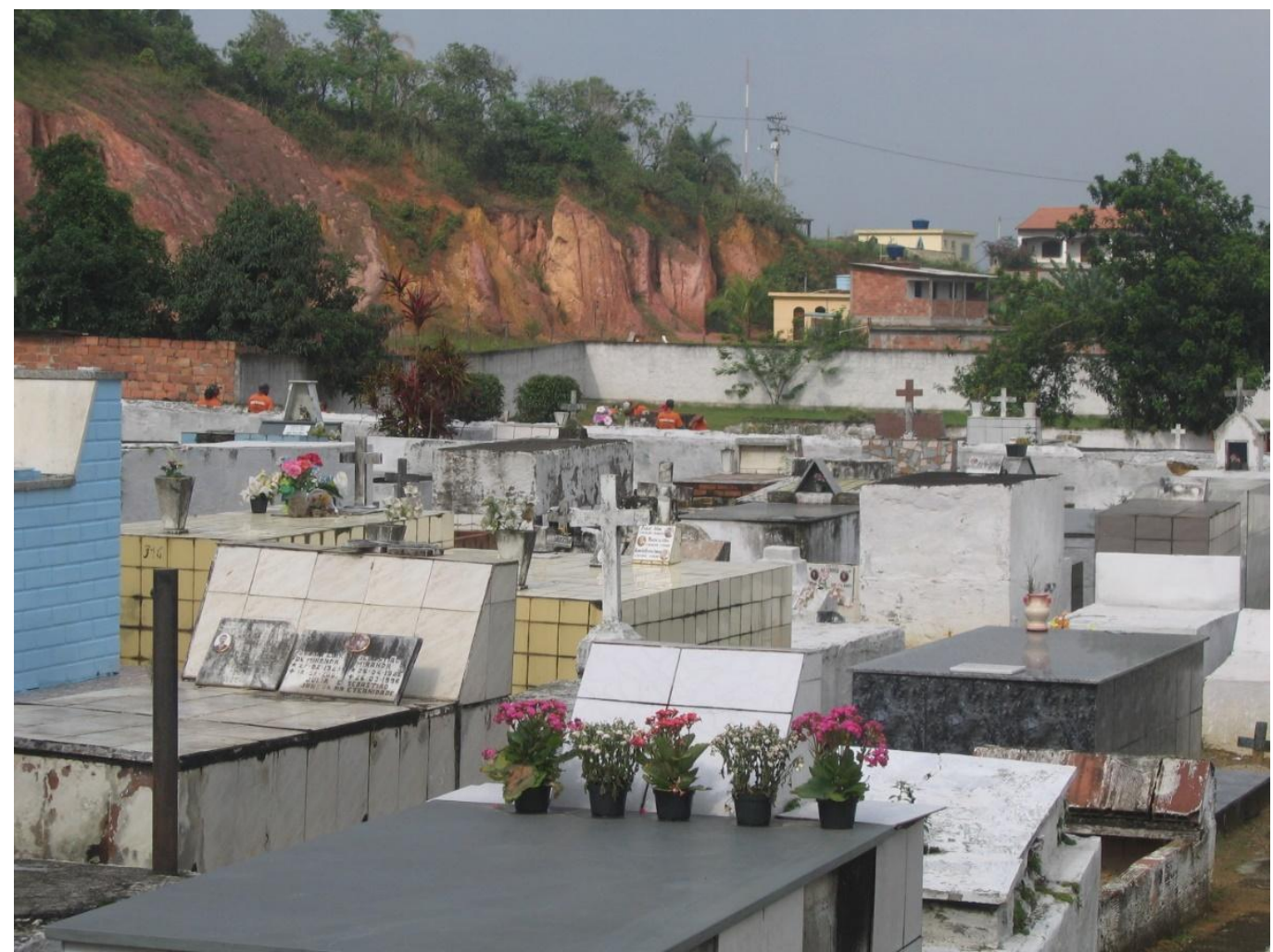

Foto 4 - Paisagem cemiterial na semana que antecedeu o dia de Finados. Ao fundo, os funcionários da prefeitura (de uniforme laranja) varriam e capinavam. No primeiro plano observam-se algumas sepulturas já adornadas com flores. Foto: Andreia Vicente. 


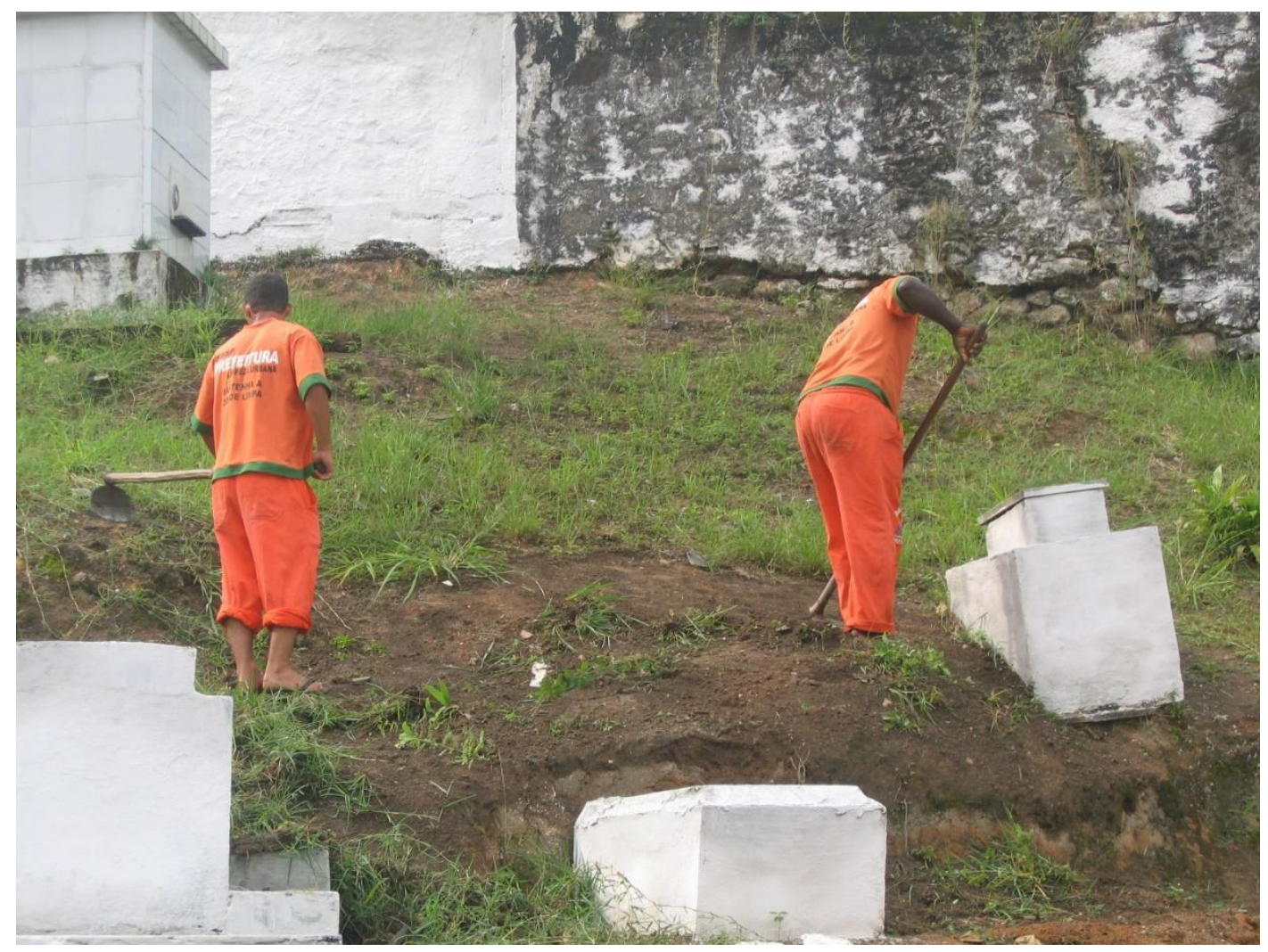

Foto 5 - Duas semanas antes do feriado, funcionários da prefeitura capinavam o cemitério. É possível perceber que o terreno é acidentado na parte mais próxima a Igreja de Nossa Senhora da Guia. Por conta da erosão na elevação, algumas sepulturas estão parcialmente desenterradas. Ao fundo, no detalhe, vê-se o muro da Igreja. Foto: Andreia Vicente.

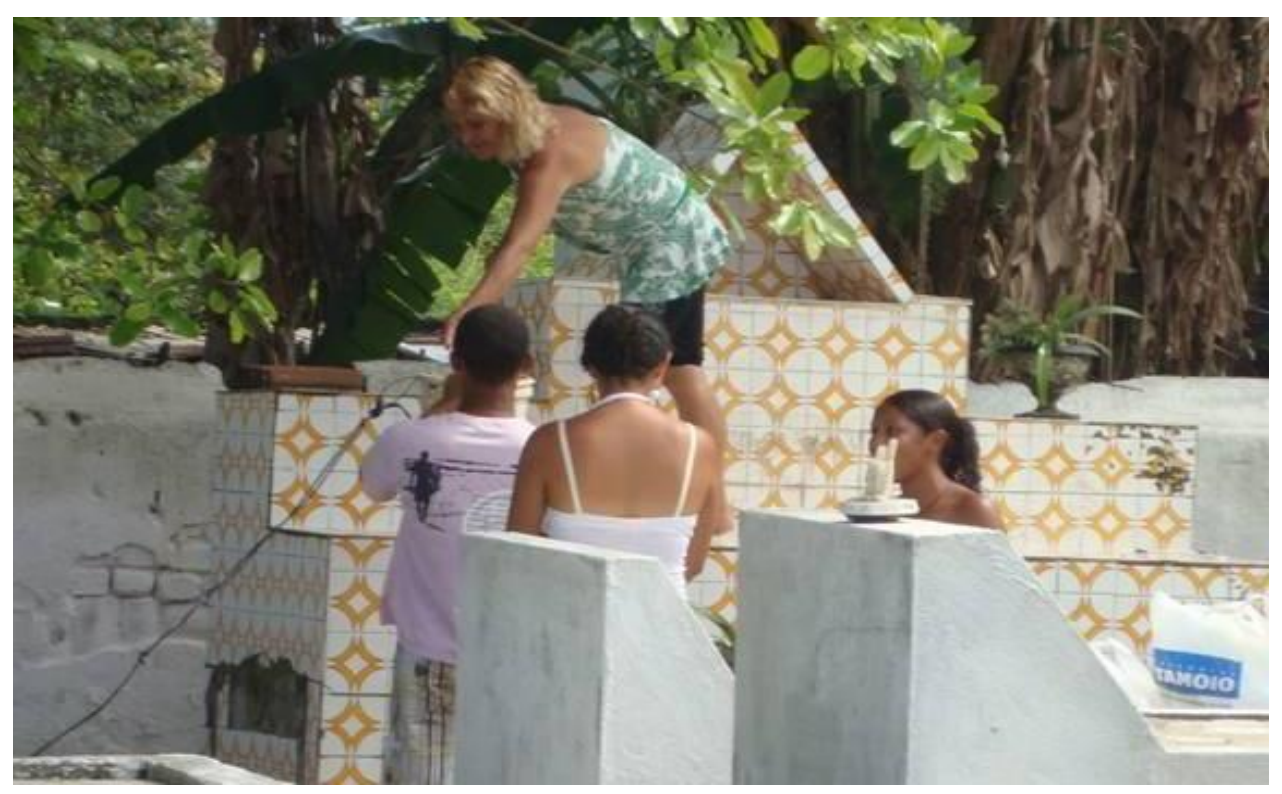

Foto 6 - Na véspera do feriado, uma família limpava uma sepultura. Para a limpeza eles utilizavam água, baldes e vassouras. No túmulo da frente, no primeiro plano da fotografia, há velas acesas em outra sepultura. Foto: Andreia Vicente. 


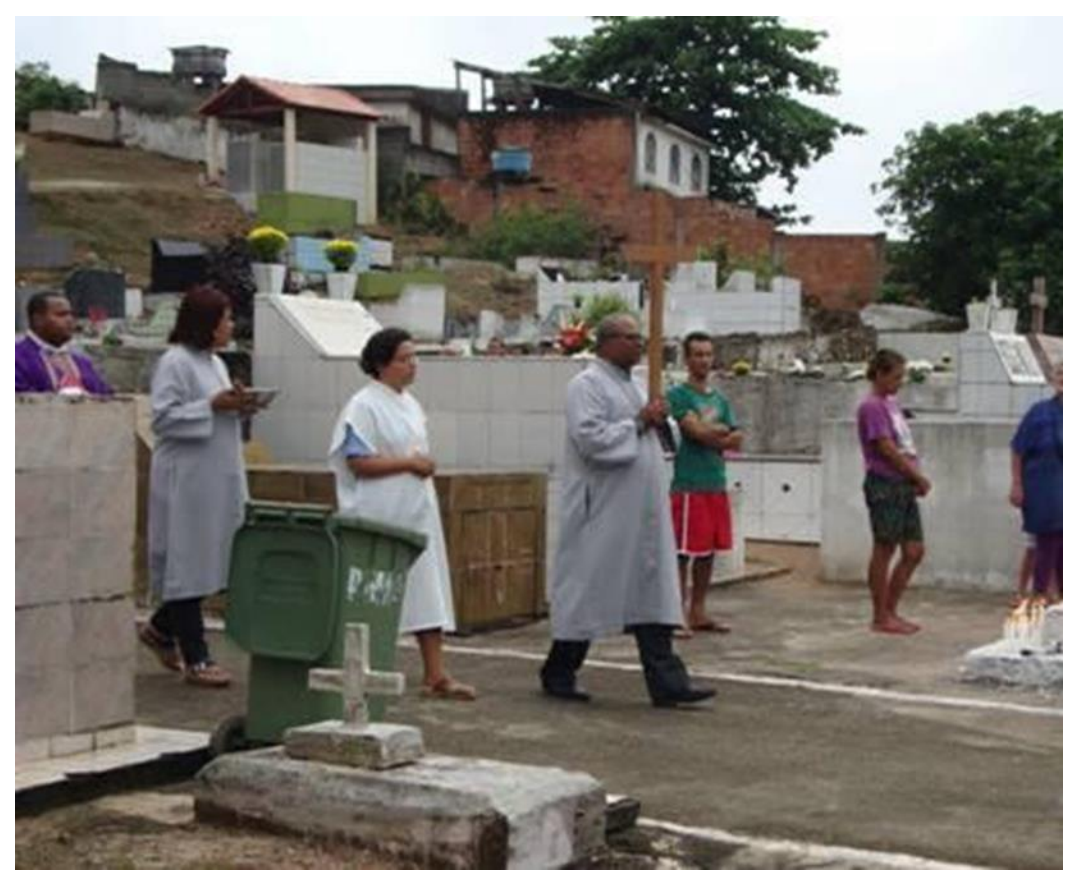

Foto 7 - Procissão seguia em direção ao cruzeiro. O auxiliar segurava a cruz de madeira, seguido por duas mulheres da Legião de Maria, uma delas tem em suas mãos o pote contendo o nome dos mortos. Por último, o padre. Foto: Andreia Vicente.

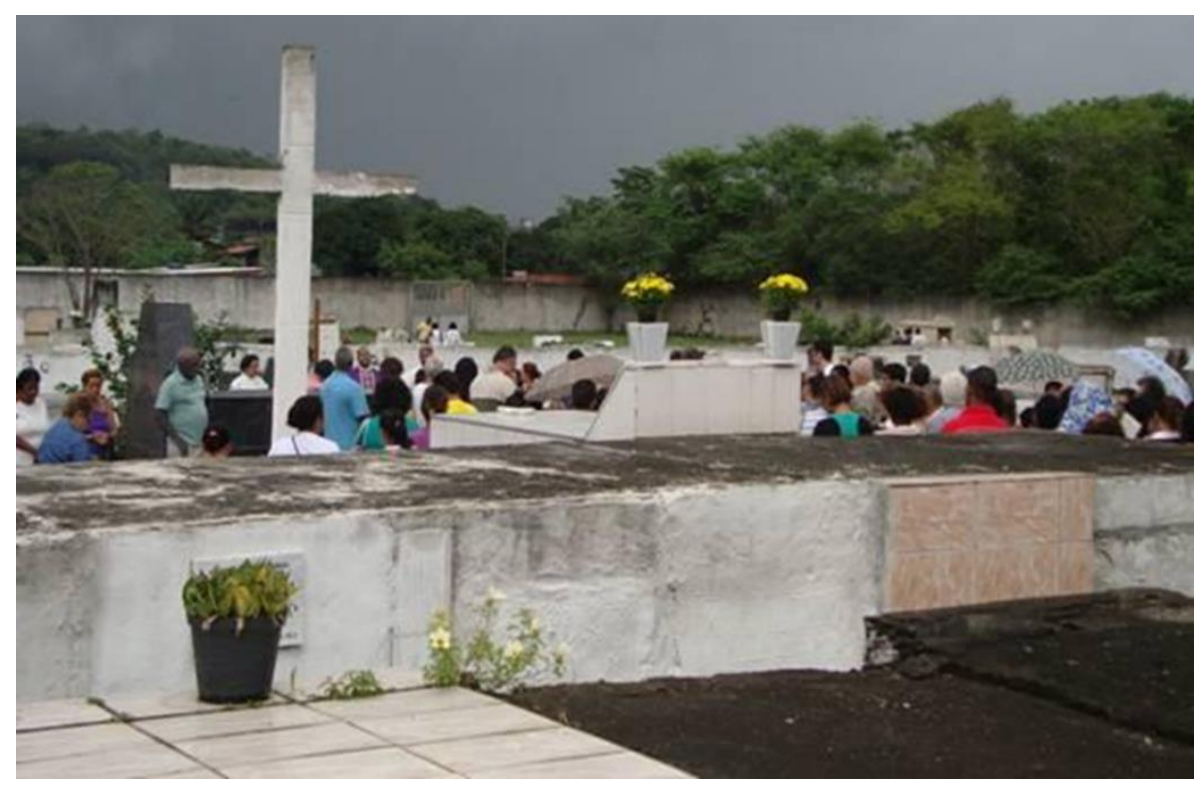

Foto 8 - O padre posicionado atrás do cruzeiro e diante da cruz de madeira proferiu a benção dos mortos cercado por muitos enlutados. Foto: Andreia Vicente. 


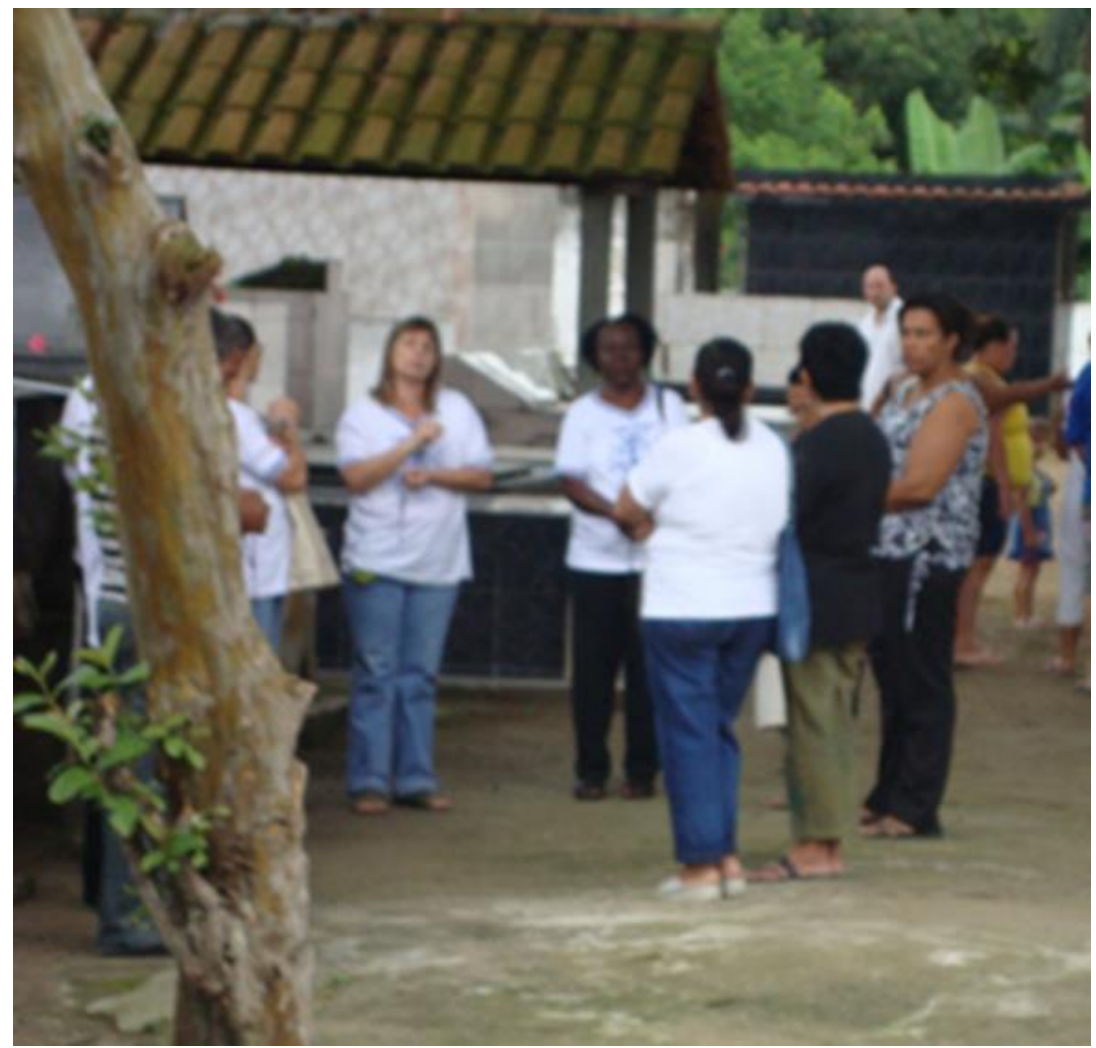

Foto 9 - Senhoras da Legião de Maria cantavam e rezavam pelos mortos nas imediações do cruzeiro. Foto: Andreia Vicente.

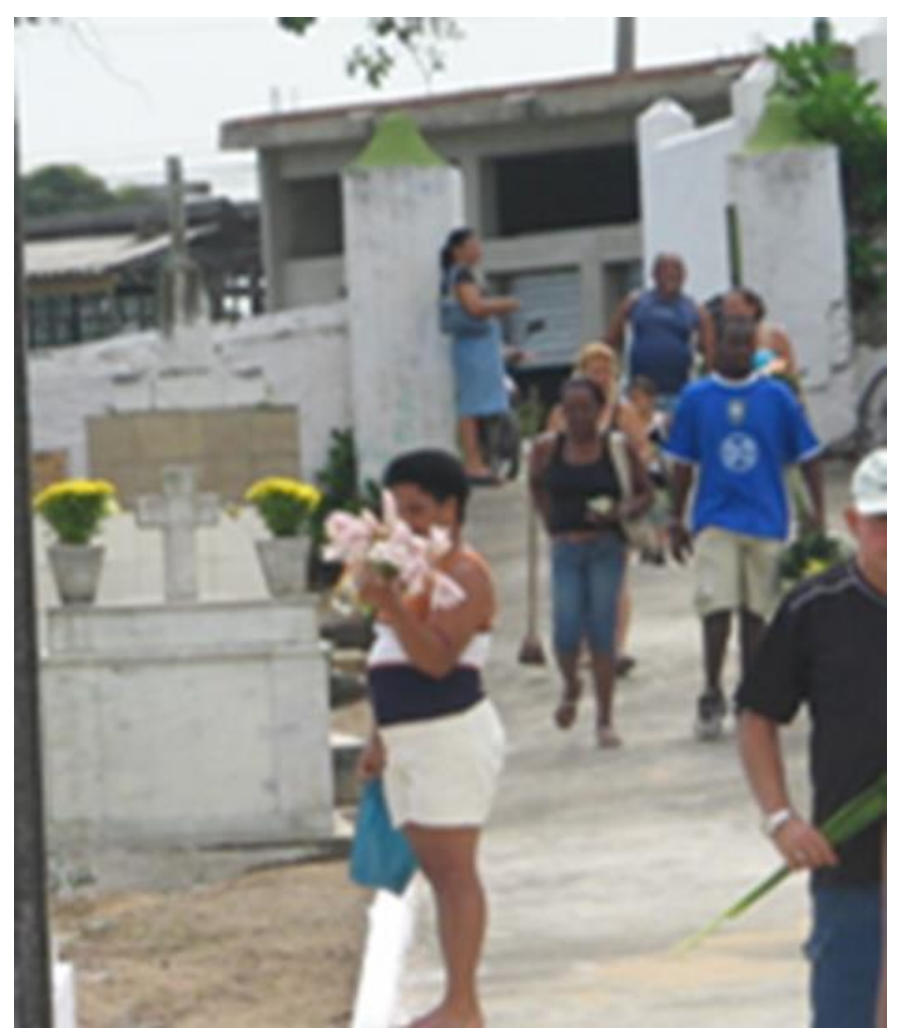

Foto 10 - Enlutados chegavam ao cemitério trazendo diversos objetos: vassouras, flores velas. Diante do portão, uma evangélica da Igreja Assembleia de Deus distribuía folhetos. Foto: Andreia Vicente. 


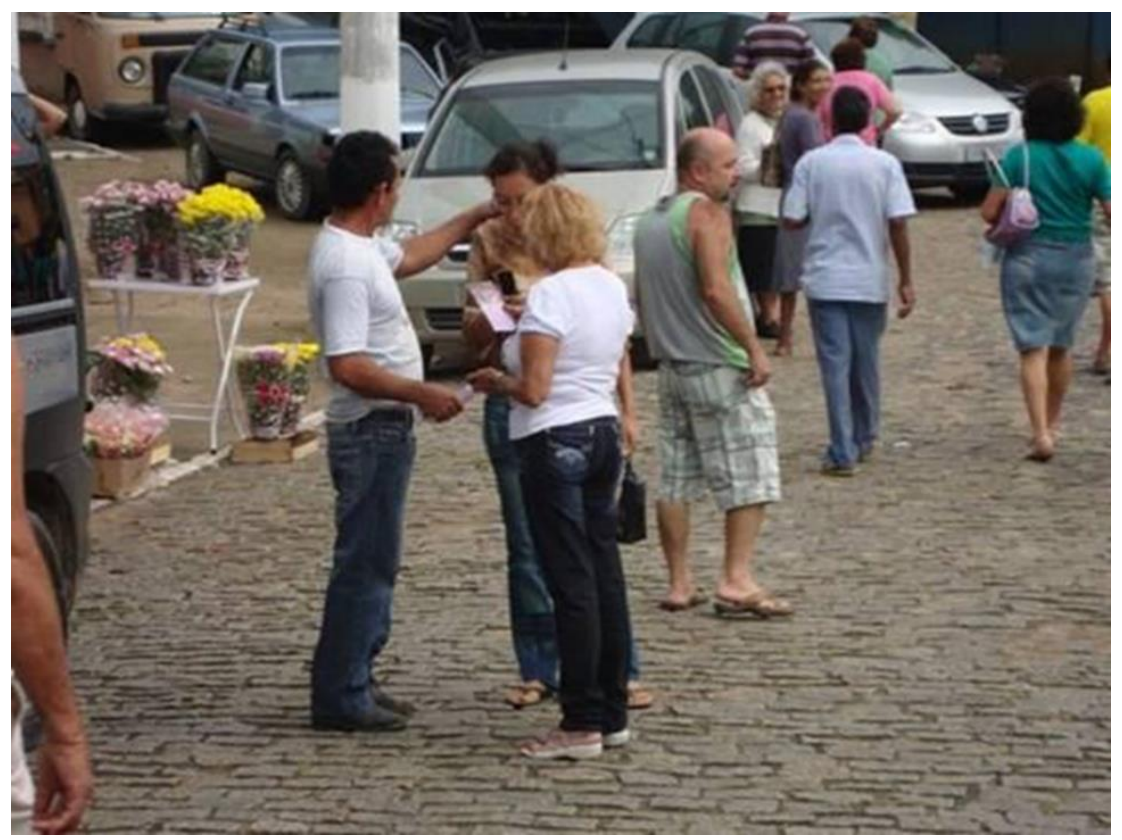

Foto 11 - Em frente ao cemitério, na rua, um evangélico da Igreja Batista Central de Mauá distribuía folhetos e conversava com duas enlutadas que passavam diante dele. Foto: Andreia Vicente.

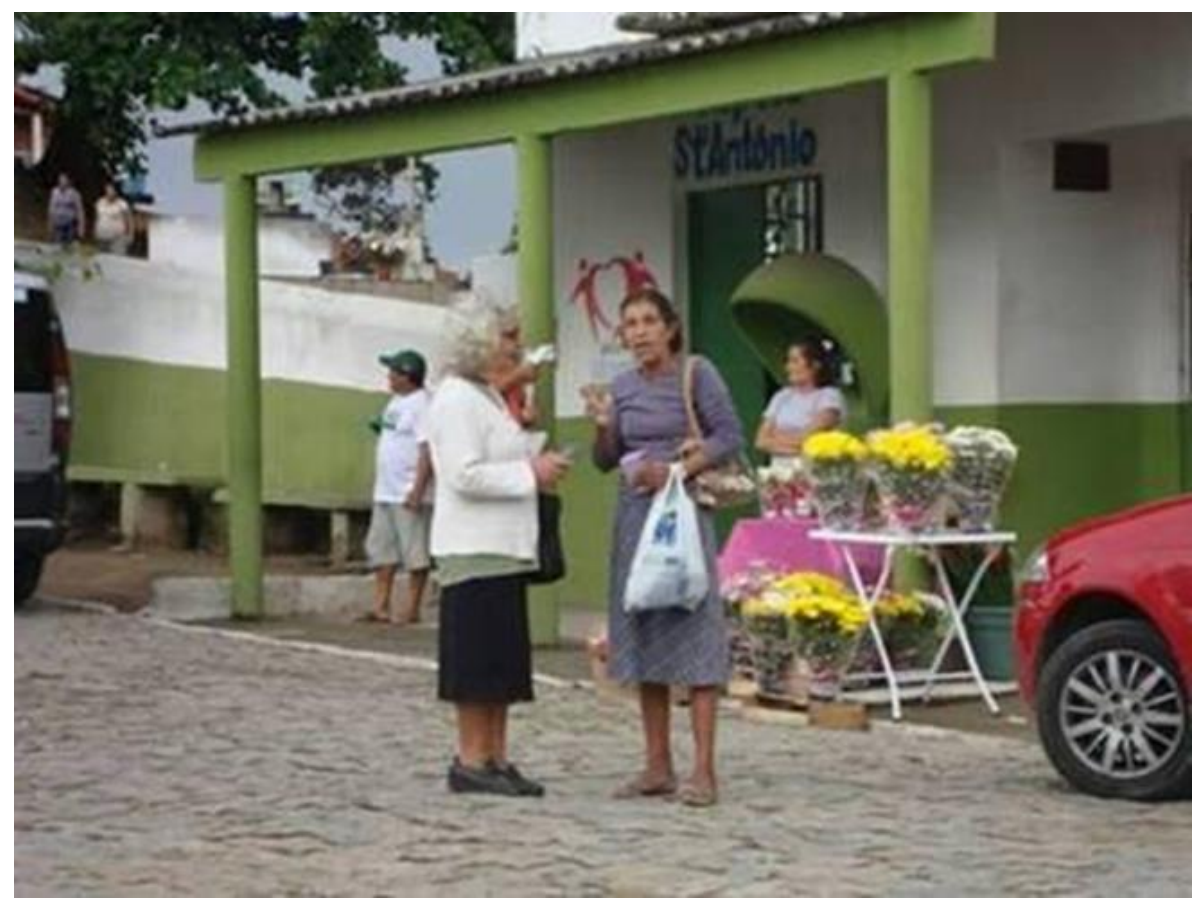

Foto 12 - Duas evangélicas da Igreja Adventista do Sétimo Dia estavam paradas em frente a capela Santo Antônio. Elas conversavam e distribuíam folhetos. Foto: Andreia Vicente. 


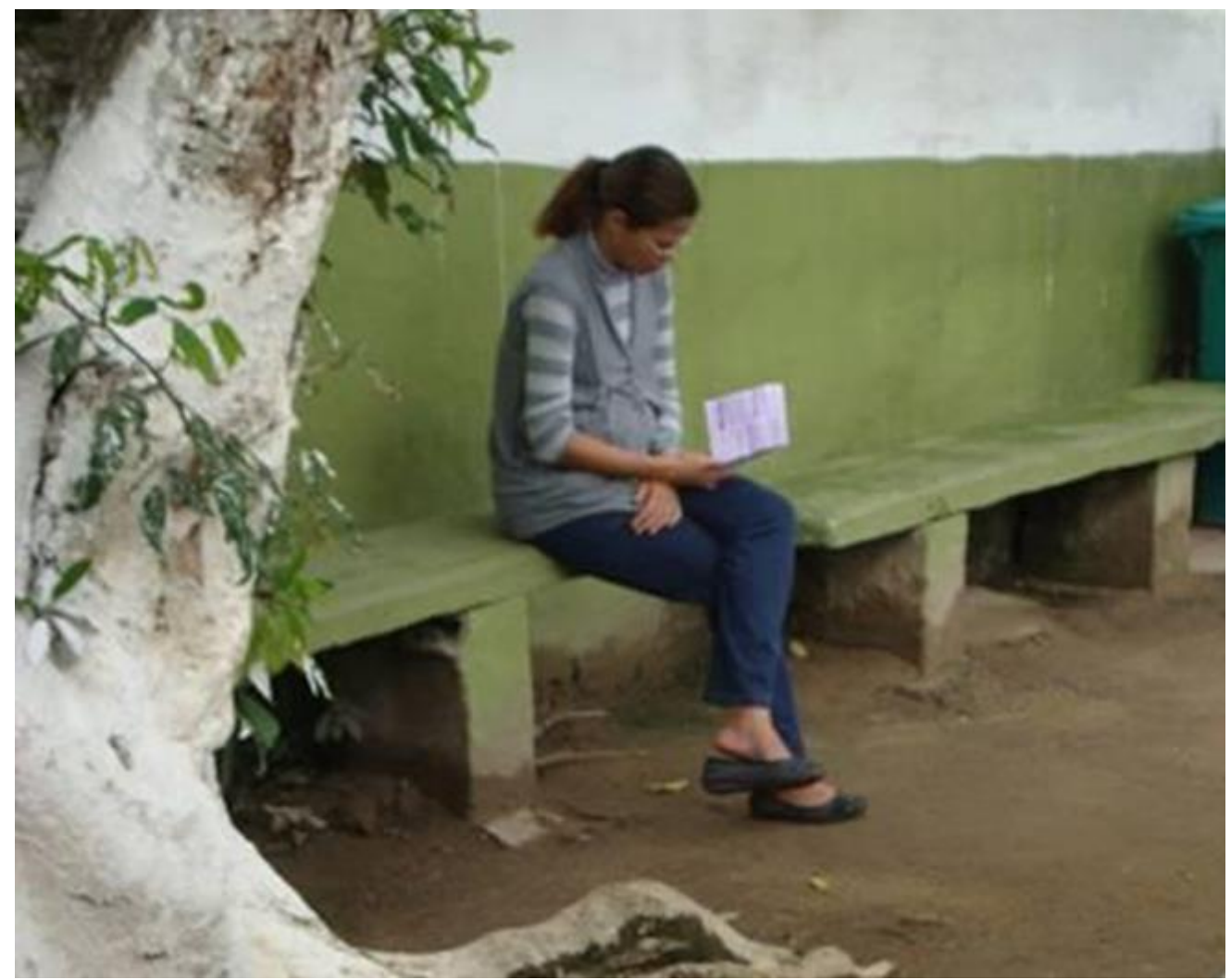

Foto 13 - Érica estava sentada no banco ao lado do portão do cemitério lendo o folheto que havia recebido das mãos de um dos evangélicos. A epígrafe que abre o ensaio é a fala dela transcrita a partir de uma entrevista feita naquele momento. Foto: Andreia Vicente.

\section{Referências:}

REIS, João José dos. (1991), A morte é uma festa. Ritos fúnebres e revolta popular no Brasil do século XIX. São Paulo: Companhia das Letras.

RODRIGUES, Claudia. (2005). Nas fronteiras do além. A secularização da morte no Rio de Janeiro, séculos XVIII e XIX. Rio de Janeiro: Arquivo Nacional.

VICENTE DA SILVA. (2011), Ritualizando o enterro e o luto evangélico: compartilhamento e incomunicabilidade na experiência da finitude humana. Tese de doutorado em Ciências Sociais. Universidade do Estado do Rio de Janeiro.

Recebido em: 13/10/2017.

Aprovado em: 17/12/2017. 